Journal of Law \& Social Studies (JLSS)

Volume 3, Issue 2, pp 87-92

www.advancelrf.org

\title{
Conceptualization of the Penology System under Islamic Criminal Law
}

\author{
Muhammad Asif Safdar \\ Assistant Professor of Law, Gillani Law College, \\ Bahauddin Zakariya University Multan, \\ Email: asif.safdar6@gmail.com, \\ Dr. Rashida Zahoor \\ Assistant Professor, Department of Law, \\ University of Sahiwal, Sahiwal, Pakistan \\ Email: rashidazahoor@uosahiwal.edu.pk \\ Khurram Baig \\ Phd Law Scholar Gillani Law College \\ Bahauddin Zakariya University, Multan \\ Advocate High Court \\ Email: mkb5729@gmail.com \\ Dr. Rao Imran Habib \\ Assistnat Professor, Gillani Law College \\ Bahauddin Zakariya University Multan \\ Email: raoimranhabib@bzu.edu.pk
}

\begin{abstract}
Islam propounds a culture where everybody follows the rules. Islam aims to preserve peace and tranquillity within the society and thus takes all required legal action to ensure the community against disruptive elements. The notion of retribution in Islam is not the primary law of Islam. They are only imposed as a requirement or series and a vindication of the primary structure of Islamic society. Criminal activity within the revered Islamic order of society is not condoned. Islam aims to change the world by changing its human adherents. Shariah law is focused on the individual rights of persons, but those rights only exist within a framework that stresses the rights of other people. Islam is not against the relative culpability of offenders and how circumstances regulate illegal conduct. Islam is the only religion where its laws and regulations are enforced according to a particular set of laws and regulations. Islam uses a system of proportional punishment. Islamic punishments are entirely justified because Islam takes complete steps to deter crime and inculcates offenders' moral conduct. The Islamic Criminal law has accepted several crimes by offering deterrence, reformative, retaliate and other kinds of punishments to uphold harmony in the community and rehabilitate the offenders. This paper focuses on the Islamic penology and the concept of crime and their punishment and explores its social, historical, and current value.
\end{abstract}

Keywords: Islam, Qisas, Tazir, Punishment, Compensation, Crime

\section{Introduction}

Today, the world is experiencing a horrific scenario of crime, violence, murder, and a concerted effort to undermine the very foundations of social order that maintain peace, tolerance, harmony, and human dignity. It is necessary to protect society from the evil acts of the criminals and the hoodlums. A life without fear should be free from tension and anxiety. Islam is the only philosophical system that explicitly discusses the problems and deals with the connection between moral issues and their human influence with the least sense of evasion. Islam is not only a religious system, but also a way of life that involves a range of ethical and moral standards, as well as legal norms that are applied in society and state life. Islam provides a strong sense of spiritual culture, where religion is an essential 
social force that induces social prohibitions and leads to a low crime rate. First, the Quranic interpretation provides a given solution to the issues and then explores their philosophical implications. Criminal liability means that a person should be penalized for any crime, no matter if he knowingly commits it, as long as he knows what he is committing and what may be its consequences. Only those living people who are under responsibility are held accountable by Islamic criminal law. Punishment can, under the deterrence principle, discourage other persons from committing illegal actions. The sentence acts as a deterrent to the rest of society and clarifies that illegal activity will not be accepted and punished. The Islamic notion of retribution is not motivated by a sense of vengeance or rage or malicious grudge. Instead, it is a way of purification and spiritual uplift. In the criminal's mind, Islam instils that God Almighty Himself is the real judge from whom he can never hide his wrongdoings. Islam's law contains a detailed perspective on life. The Islamic definition of crime for all scholars and schools of law is common, eternal, unchanging and unanimous.

It is difficult for a person to live alone in daily life. There is a need for each person to form social relationships with others. Much as in all human cultures, there are families and neighbourhoods. Aristotle was the first author to understand men as social beings(Ghazi, 2006). It is claimed by Simon Roberts that: At the centre of daily life in one's own everyday life.

Certain patterns of habitual behaviour are practiced by members of a group, providing a framework for another member to anticipate how another is likely to behave under given conditions or how his own acts will be perceived(Harding \& Ireland, 1989).

There is a significant argument we should remember about the latest study researchers are doing on the notion of punishment. For example, relative to other forms of theft, the punishment for theft that meets all the requirements specified in Islamic criminal law will be the most extreme since it requires the most drastic of punishment that is cutting off a hand. "hadood", "qisas" and "diyat" are found specifically in the Islamic Criminal Law Quran and Sunnah in most Muslim countries (Porokhova, 2003). Robert Spencer remarks: "Two harsh punishments—stoning for adultery and cutting off hands for theft-define Islamic Sharia law, for many Westerners, and indeed, one feature of the medieval era was its uniformity and lack of connectivity with the known world"(Spencer, 2006). Before labelling Islamic punishments as barbarous, it would be advisable and prudent to bear in mind an essential principle that such punishments are not allowed to be executed where social, political and administrative order is not entirely in accordance with the spirit of Islam. It would be an enormity to enforce Islamic punishments before ensuring the other prerequisite of Islamic morality and social order (Madudi, n.d.).

To find out its meaning and importance in modern times, this paper deals with the Islamic justice system and criminal law.

\section{Crime and Punishment}

Law-based punishment is simply a social regulation tactic, and its employment is justified to the degree that it ultimately preserves social justice by law, such as community. There are two kinds of injunctions within the Holy Quran.

\subsection{Moral}

Morality includes all the ways of fostering human identity.

\subsection{Punitive}

Punitive means those laws that become a social crime through violations, and moral means those laws that can not be categorized as a social crime. The Quran says: "do not walk arrogantly on the earth" (The Quran, Al-Isra: 37). The Quran says that his failure to comply with this injunction is not a social crime. "Do not go near adultery or fornication" (The Quran, Al-Isra:32). It is clear that non-compliance with this injunction is a social crime. However, the above division is arbitrary only to understand the problem under consideration; otherwise, all the means of cultivating human personality are protected by the basis of each Quranic injunction aimed at correcting and importing the morals and 'morals'.

\subsection{Crime}

Under the Islamic Penal Law,' Hadood' crimes are regarded as the most severe, hideous and severe crimes for which God has placed deterrent and preventive punishments to discourage those who have similar criminal habits and prevent the wrongdoer offending again in the future. These are the offences against public morality referred to in Islam as 'Haqooq Allah, Allah's argument, and the Qur'an imposes strict' hadud 'punishment.

\subsection{Punishment}

Punishments are the instrument that culture has used from time immemorial to communicate its denunciation of wrongdoing to guarantee people's security and harmony in society. It is intended to carry out one of the most fundamental duties of the state by minimizing the commission of crimes to protect people's life, liberty, and property.

\section{The Principles of Islamic Law}


The Shariah Islamic law defines the law of God and gives instructions in the best interests of man for the direction of life. Its aims are to show man the best way and provide him with the most prosperous and most profitable ways and means to satisfy his needs. There is nothing in it that threatens to waste your powers, or to overpower your normal desires and needs, or to ruin your spiritual desires and feelings (Madudi, 1992). The criminal law of Shariah is essentially divided into three major groups of crimes, Hadood, Qisas, and Tazir.

\subsection{Hadood}

Hadood offenders are the first category. As required in the Quran and Sunnah, the community penalizes these crimes and is punishable by fixed penalties(Bassiouni (Hrsg.), 1984). The crime and sentence are determined with some flexibility for the judge, depending on the motive of the accused and the essence of the evidence. Crimes against God are called hadood in the Islamic penal system. These violent crimes are violations of the Islamic State's special cultural norms. Hadood's crimes would warrant divine disappointment as violations of God's rights. An act of declaring war against an Islamic sovereign nation is tantamount to declaring war against Allah and His Messenger, and an act of aggression against Islam. It is clearly stated Holy Quran: "There is no reward for those who fight against Allah and His Prophet and revolt against the reality in the country, except that they will be killed or crucified or their hands and feet will alternately be cut off or will be expelled" (The Quran, Al Noor:2).

\subsubsection{Fornication}

Fornication refers to sexual activity with a person, not one's husband or wife, and the Quran's punishment for this act is hundred lashes. Men are tied to the waist of women's garments and flogged with a leather whip. In Quran, the punishment for flogging is mentioned. Quran says: "A hundred lashes flew at both of them, the woman and the man accused of fornication: in a matter commanded by Allah, let no sympathy move you in their situation" (The Quran, Al-Noor:4).

\subsubsection{Adultery}

Adultery means sex that is extra-marital. For those guilty of adultery, Islam prescribed the punishment by stoning to death. Two requirements that must be fulfilled before the judgment is executed are set out in Islamic criminal jurisprudence. The first of these is that four eyewitnesses must confess. Without any element of duress, it must be a voluntary confession. Only after four eyewitnesses have attested, then the punishment will be carried out. Secondly, it is the responsibility of the court to create the truth that there was actual penetration of the male's penis into the vagina of the female by investigating all confessions. Islamic law demands that the four witnesses to the eye must explicitly affirm physical examination of the real intercourse. From the Islamic viewpoint, adultery and fornication are not private prerogatives. It represents a severe violation of the normal ideals of society. This is a dishonour and a brutal attack on the woman's family. Fornication and adultery are called Zina. Filing a false complaint of Zina is punishable by "qazaf". Defamation violates the credibility of a child born of a woman and the Islamic provision of eighty lashes for slaves, and forty lashes for free persons: the Quran says, " Those who force it on women in marriage and do not produce four witnesses, subject them to eighty lashes" (The Quran, Al-Maidah:38).

\subsubsection{Theft}

In the Islamic legal code, the act of robbery is expressly condemned. Intensive and deliberate must be the act of stealing. The thief must be conscious that someone else owns the house. The property must have been held in a safe position which was forcibly stolen by the thief. The crime of theft/stealing is considered a surprising and scandalous experience for someone to invade another person's home by forced entry and stealthily. The theft penalty is set in the Quran: " As of the thief, he or she will be punished by being cut off of hands" (The Quran, Al-Maidah:38). Hand amputation criteria is contingent on strict criteria. In the case of the stolen object, the value determines whether it would be in the public interest to prosecute the thief or not. In Islamic criminal law, one-quarter of a dinar or equivalent must be paid for products taken in the stolen good. The stolen goods must not be unclaimed or belonging to no one. The property must have been kept in a safe and secure location, which is called 'hirz'. 'Hirz' also means keeping anything safe and protected by keeping it in a private location.

\subsubsection{Drinking of Alcohol}

Islam has confirmed that alcohol is a really bad thing that you have to abstain from and not touch. Because the drinking of alcoholic beverages can contribute to the conduct of other crimes, it is prohibited. In the Hadith, Ibn Umar quoted the Prophet when he said: "Every intoxicant is wine 'khamr', and every intoxicant is prohibited"(Sunan Ibn-I-Majah, Volume 3, Book of Intoxicants, Chapter 30 Hadith No. 3392, n.d.). Jabir also said that Prophet Muhammad made the following statement: " If a significant amount of something induces intoxication, a small amount of it shall be forbidden" (Sunan Abi Daood, Hadith No. 3681). According to the Islamic hadith, the penalty for drunkenness and drunkenness with others is 80 lashes. It is not mentioned anywhere in the Quran. When an alcoholic was brought before Prophet Muhammad, according to Aras bin Malik, the Prophet said: the man should be punished 
by 40 lashes with two palm branches (Sunan Abi Daood, Hadith No. 3681, n.d.). Anas Abu Bakar reported that Caliph Umar, consulted for a consensus on the punishment for drinking alcohol and Abdur-Rahman bin Auf said: " The penalty for drinking wine is usually 80 stripes (Sahih Al-Bukhari, Hadith No. 4616).

\subsubsection{Hirabah}

The armed robbery of innocent people is included in hirabah, which is a type of banditry crime that involves armed robbery, forcible entry into homes or businesses with weapons, and forcible entry into homes or businesses without weapons. According to Islamic criminal law, carrying out violent actions is an act of declaring war against the society. There are many items that await certain suspects in courtrooms, from a simple fine to a lifelong disability. The Quran says: "The penalty of those who wage war against Allah and his messenger will be death or beheading, or having their hands and feet cut off, or being exiled from the country (Sahih Muslim, Hadith No. 4227). The Shariah Court is free to assess the required ratio of punishment for each offence. If the thief takes money and kills the person he is stealing it from, he may be charged with murder. If the thief steals money without killing or harming one, only his hand is amputated. If he is not paid for his murder, the murderer must be hanged. If he threatens innocent people without actually carrying out the assassination, he may be expelled from the country.

\subsection{Qisas}

Qisas means "equality". Cases which come under Qisas are murder, voluntary or accidental killing or injury, intentional or unintentional physical injury. Murder is the most serious of all crimes in the Islamic criminal law. The Quran says: " Do not kill the person God has forbidden to kill except when there is just reason" (The Quran, AlMaidah:33-34). The Quran stated in another place: " Do not snatch life which Allah has made sacred except by way of justice and an effective legal procedure" (The Quran, Al-Isra:33-35). According to Shariah, homicide can be divided into two categories:

1. 'Qatl-e-amd: (Intentional killing)

2. 'Qatl-e -khata: (Mistaken Killing)

Killing with intent is outlawed by the Islamic State since life is sacred and should only be taken by a competent Shariah court if the person is sentenced to death by the Shariah court in question. If any of the following events occur: a married man who commits fornication; a life for a life; or someone who walks away from his faith and abandons the culture, according to Ibn Masood, Muslim blood that has not been spilt is permitted to be shed. (The Quran, Al-Inam:151'.

'Qatal-e-khata' taking someone's life accidentally is a lethal act which mistakenly causes death. The act of accidentally killing someone does not fall under the purview of qisas and is not punishable by death. Muslims are not permitted to kill other Muslims unless it is an accident, according to the Quran. The Quran states the Islamic viewpoint: A believer should never harm a believer deliberately. It is necessary to free a believing slave and reimburse the family of the deceased in such a situation. If the deceased was a believer who belonged to people you were at war with, the liberation of a believer should be appropriate. If a member of the people you have a treaty of mutual alliance with is murdered, his family should be compensated, and a believing slave should be set free. A temporary fast is recommended to help those who cannot fulfill the criteria for a fast for two consecutive months (Sunn Ibn Maza, Hadith No. 3931). It is a general law stating that, according to the Islamic state, if a non-Muslim citizen of a country which has a pact with the Islamic state dies, is killed during the war, or was killed in revenge for that country's actions, then that person must be punished in order for the Islamic state to rule that country by killing that person. The case has a verdict of death. If a government official carried out a killing by mistake, they will presumably do penance for their sin, such as making a donation to charity, fasting, or paying a fine. Homicide is either induced by a person or an arrangement between two or more individuals. If an object is lost, you will be personally obligated for the missing item and will be penalized.

The second form of comparable violations are qisas and diyat crimes. As in the case of qisas (the law of compensation in Islamic law) on murder and causing harm, in Islamic law, when a victim experiences an injury, the perpetrator must be punished with the same injury he/she inflicted upon the victim. Victims and their next of kin have the right to claim damages or obtain compensation at law for loss or injuries incurred by the crime. Often, those who are involved in an abusive relationship are able to avoid retaliatory abuse. A qisas and diyat crime typically belongs to one of two categories: murder or battery. In Islamic law, these offences are thus treated as a private matter and not a public offence. Intentional killing or inflicting of great bodily harm, under the contract of Qisas, with the acceptance of blood money "diyat" as punishment must be an Islamic practice. According to the statute, the victim or spouse of the victim has the right to pardon or recommend a lighter punishment to the convicted person. 


\subsection{Tazir}

In Islamic law, there are three types of offences. One of these is 'tazir'. According to the Islamic law, officials who do not punish minors recognize that these offences are punishable by fines left to the discretion of the monarch or the judge Qazi. You are not allowed to be ordered by the Sharia to enforce them as penalties for these crimes, as they can invade citizens' rights or are simply too troublesome to be enforced. Tazir or discretionary punishment in Islam is also broad and left up to the ruling of the presiding body. The word "tazir" literally means "something prohibited." It is the responsibility of public officials to lay down guidelines on this conduct-this conduct must be penalized. Right from the outset, these rules should take the Shariah into account. An example of a tazir crime is forbidden, which is the trafficking of persons. Although it is not specified in the Quran or the Sunnah, it constitutes a direct infringement of the right to personal protection, one of the five essentials of Islam. Tazir is used for three types of cases:

1. Crimes which are punishable under hadood (Muslim religious laws), including for example adultery, illegal cohabitation, and petty theft.

2. Crime actions generally punished with hadood, but when the hadood penalty is substituted by tazir for reasons of procedural doubt or the accused's situation;

3. All actions which are not punishable by hadood under the provisions of the rule.

\section{Criminal Procedure}

Neither in the Quran nor in the Prophet's tradition do we find any procedural protections. But are left to the discretion of the monarch to assess the well-being of the public. The Ruler's interpretation of procedural laws is influenced by the Quran (Awad, 1982).

As human beings are considered to be the most precious of Allah's creations, their rights must be upheld and cared for just as much as others. The warning against the oppression of individuals is repeated a significant number of times 299 in the Quran (Bassiouni, 1982); the word justice and equality is repeated at 16 times in the Quran (Al-Saleh, 1982).

The laws must be implemented fairly regardless of the religious or economic status of the people. Holy Prophet said, "All men are equal as teeth of the comb. None of the Arabs are superior to a non-Arab except in terms of piety". Prophet Muhammad vowed that his daughter Fatima would be punished the same as any other criminal if she committed theft (AL-AWWA, 1982). The main exception to the normal trend of equality is what is called slavery. Slaves were being given less protection than the free and therefore not being excused from any types of criminal liability.

A legislative or judicial decision must be in compliance with the Sharia law; otherwise, it is void. Quran says, "Who, then, judges not according to what Allah has sent- they are unbelievers" (The Quran, Al-Maidah:47-.

Provided that the laws of the Islamic Sharia provide the accused with the right to be free of coercion, to have a free and fair trial, and are absolutely opposed to unwarranted searches and seizures, there is no reasonable doubt that the accused should be considered innocent.

\subsection{Arrest Before Trial}

The bail and pre-trial detention are not widely practiced in the Sharia. Islamic jurists accept that an accused should not be detained prior to trial because an allegation alone is insufficient to warrant detention. Pre-trial detention often deprives people of their right to freedom of movement.

\subsection{Interrogation Before Trial}

Complaints are investigated by the police. In common law, the accused has a right to remain silent and restricted use of the accused's silence as proof of guilt (Awad, 1982). The person accused is to be treated humanely, and the person accused should be encouraged to deny committing the crime. The Prophet once advised the denier of adulterous ties to withdraw their own confession. The Quran forbids torture and cruel treatment as a means of interrogation. This kind of treatment threatens the dignity of the victim and the legitimacy of the Islamic legal system because it creates a chance of false confessions. The use of torture is against religion (The Quran, Al-Isra:15).

\subsection{Right to Give Evidence and Assistance by Counsel}

In Islamic law, the criminal defendant and his or her attorney have right to present evidence at trial and to be represented by lawyers at pre-trial questioning, at trial, and on the day of sentencing. The right to counsel was recognized based on the Islamic principle of "protected interests" faith, feelings, speech, and privacy. The right to selfpreservation requires safeguarding individual personal liberty and integrity and the defence of individual well-being (Peretz et al., 1984). The principle of "protected interests" acknowledges the right to obtain services from others to protect the individual's interests. The right to advice relies on the right of assistance by an advocate.

The freedom of persons or their legal representatives to present proof appears consistent with Islamic values. When Holy Prophet awarded Ali the governorship of Yemen, he gave him advice: When two opponents come to arbitration, do not rule on the one until you have heard the other equally. The accused and his lawyer are to be told of 
the charges which are being brought against him or her and what facts will be used to support those charges. The accused has the right to attend all hearings about the allegations, the right to be aware of what happens, and the right to be given the opportunity to submit rebuttal evidence.

\subsection{Search and Seizure}

Islam respects the privacy and sanctity of the individual. Quran says, Do not enter other people's houses until they give you leave to enter (The Quran, Al-Noor:27). The individual's residence, property, and correspondence may only be searched if it is considered appropriate to the general protection of the country. An arrest warrant must be issued by the judge of government with probable cause to suspect an accused person committed a crime.

\section{Conclusion}

The Islamic jurisprudence integrates most types of alternative punishments developed by contemporary restorative justice models. Today, Islamic justice systems should be part of what becomes an internationally recognized framework for restorative justice. Islamic law, the most consequential of all past or current legal systems, is the primary source of human rights. Islamic sentencing mechanisms are not cruel or counterproductive in today's culture. Islamic punishments are more powerful and consequential than any other system of punishment. The psychological consequences of Islamic punishment are primarily dictated by the terror and the psychological vulnerability of life that it evokes. In the face of Islamic Sharia, the world enjoys perfect peace, stability, and tranquillity. These are the necessary conditions for human progress. Islamic punishment serves to create and maintain a clean society that is built on dignity and justice. A culture that upholds the importance of human life.

\section{References}

AL-AWWA, M. S. (1982). The Basis of Islamic Penal Legislation. The Islamic Criminal Justice System (New York: Oceana Publications, 1982), 127.

Al-Saleh, O. A.-M. (1982). The Right of the Individual to Personal Security in Islam. In The Islamic Criminal Justice System (pp. 55-90). Oceana Publications, Inc., London, Rome, New York Pakistan Journal of ....

Awad, A. M. (1982). The rights of the accused under Islamic criminal procedure. The Islamic Criminal Justice System, 91-107.

Bassiouni (Hrsg.), M. C. (1984). The Islamic Criminal Justice System. Verfassung in Recht Und Übersee, 17(2), 272273. https://doi.org/10.5771/0506-7286-1984-2-272

Bassiouni, M. C. (1982). Sources of Islamic Law, and the Protection of Human Rights in the Islamic Criminal Justice System. The Islamic Criminal Justice System, 3, 23.

Ghazi, M. A. (2006). State and Legislation in Islam. Shariah Academy, International Islamic University.

Harding, C., \& Ireland, R. W. (1989). Punishment: rhetoric, rule, and practice. Routledge London.

Madudi, S. A. A. (n.d.). Tafheem Ul Quran.

Madudi, S. A. A. (1992). Towards understanding Islam.

Peretz, D., Moench, R. U., \& Mohsen, S. K. (1984). Islam: legacy of the past, challenge of the future.

Porokhova, V. (2003). quran. translation of meanings and iman valeria porokhova comments: 7th ed. 2003. moscow. 7.

Quran, Al-Isra:15. (n.d.).

Quran, Al-Maidah:47. (n.d.).

Quran, Al-Noor:27. (n.d.).

Sahih Al-Bukhari, Hadith No. 4616. (n.d.).

Sahih Muslim, Hadith No. 4227. (n.d.).

Spencer, R. (2006). The Truth About Muhammad.

Sunan Abi Daood, Hadith No. 3681. (n.d.).

Sunan Ibn-I-Majah, Volume 3, Book of Intoxicants, Chapter 30 Hadith No. 3392. (n.d.).

Sunn Ibn Maza, Hadith No. 3931. (n.d.).

The Quran, Al-Inam:151. (n.d.).

The Quran, Al-Isra: 37. (n.d.).

The Quran, Al-Isra:32. (n.d.).

The Quran, Al-Isra:33-35. (n.d.).

The Quran, Al-Maidah:33-34. (n.d.).

The Quran, Al-Maidah:38. (n.d.).

The Quran, Al-Noor:4. (n.d.).

The Quran, Al Noor:2. (n.d.). 